\title{
Body Composition of a Nine-Year-Old Reference Boy
}

\author{
FERDINAND HASCHKE, SAMUEL J. FOMON, ${ }^{(23)}$ AND EKHARD E. ZIEGLER \\ Department of Pediatrics, College of Medicine, University of Iowa, Iowa City, Iowa, USA
}

\section{Summary}

Utilizing available data and several assumptions, the body content of water, minerals, protein, carbohydrate, and fat has been estimated for a 9-year-old reference boy. This reference boy is leaner than the reference man ( 13.4 versus $15.3 \%$ of body weight) and his fat-free body mass exhibits greater concentration of water (75.5 versus $73.7 \%)$ and lesser concentrations of potassium $(66.8$ versus $68.1 \mathrm{mEq} / \mathrm{kg}$ ) and total minerals (4.7 versus $6.9 \%)$. If agespecific values are used for composition of fat-free body mass (rather than the conventionally used constants based on adult body composition), it will be possible to avoid underestimation of fat content calculated from data on total body water and overestimation of fat content calculated from ${ }^{40} \mathrm{~K}$ counting data or from body density determined by underwater weighing.

\section{Speculation}

By utilizing age-specific constants for calculating body fat content from indirect measurement of body composition (i.e., total body water, ${ }^{40} \mathrm{~K}$ counting, and body density) it will be possible to determine the extent of changes in fat content of the body of normal individuals and of those with specific illnesses or disorders, including obesity.

The description of a "reference man" (1) of defined chemical composition has been useful in the interpretation of data obtained by various indirect methods of estimating body composition of living subjects. If fat-free body mass (FFBM) can be estimated, this quantity can be subtracted from body weight to yield an estimate of the body content of fat. Three major methods are utilized for estimating FFBM: (1) total body water content (TBW) is determined from the volume of distribution of a tracer substance (tritium, deuterium, or antipyrine) within the body; (2) total body potassium content (TBK) is estimated by gamma ray measurement of the content of the naturally occurring radioisotope, ${ }^{40} \mathrm{~K}^{1} ;$ (3) body density is determined by underwater weighing. With each method, it is necessary to use one or more constants to permit an estimation of FFBM on the basis of the parameter studied. Thus, for the normal male adult, it is generally assumed that in FFBM the concentration of water is $737 \mathrm{~g} / \mathrm{kg}$ (1) and the concentration of potassium is $68.1 \mathrm{mEq} / \mathrm{kg}$ (14). It is further assumed that the density of FFBM is $1.100 \mathrm{~g} / \mathrm{ml}$ and that the density of fat is 0.9007 (1).

Currently, there is available no reference individual between the age of 3 years (9) and the adult. In the child and adolescent, the same indirect measurements of body composition have been made as in the adult, and the same constants have been utilized for estimation of FFBM. However, the appropriateness of these constants for the child and adolescent must be questioned. In the child, extracellular water comprises a larger percentage of body weight $(2,3)$ and, presumably, of FFMB than in the adult. The concentration of minerals is less in the skeleton of the child than

\footnotetext{
${ }^{140} \mathrm{~K}$ constitutes $0.0118 \%$ of total body $\mathrm{K}$.
}

in that of the adult (7), and therefore, density of FFBM is presumed to be less.

Combining data from a variety of sources and using several assumptions, we have attempted to establish the body composition of a 9-year-old reference boy. We were able to locate data on TBW of 11 normal boys 7 to 11 years of age $(4,8,14,15)$. These data and data on TBK from ${ }^{40} \mathrm{~K}$ counting of 64 normal boys 8 to 10 years of age $(11,13)$ are summarized in Table 1 . For height and weight of the 9-year-old reference boy, we selected the 50th percentile values for height and weight for 9.0-year-old males in the United States (16). Because mean values of weight for height of the 7- to 11-year-old boys studied for TBW and the 8- to 10year-old boys studied for TBK were close to the 50th percentile values for prepubertal boys (16), we derived the water and potassium content of the reference boy (body weight, $28 \mathrm{~kg}$ ) by adjustment simply on the basis of body weight. In addition, we reduced the quantity of TBW by $1.6 \%$ to adjust for the exchange of deuterium with the rapidly exchangeable hydrogen of organic molecules. ${ }^{2}$ Thus, TBW of the 9-year-old reference boy is $18.3 \mathrm{~kg}$, and TBK is $1619 \mathrm{mEq}$.

Utilizing these values for body height, weight, water, and potassium and data from other sources (to be identified), we estimated the content of the following: extracellular and cellular water, osseous minerals, extracellular and cellular nonosseous minerals, and total body protein.

\section{WATER}

TBW consists of extracellular water $\left(\mathrm{W}_{\mathrm{EC}}\right)$ and cellular water $\left(\mathrm{W}_{\mathrm{C}}\right)$. Because body potassium and body water occur in a fixed ratio in the extracellular compartment $(4 \mathrm{mEq} / \mathrm{kg})(20)$ and in the cellular compartment (150 mEq/kg) (12), the following equation may be written:

$$
\mathrm{TBK}=4 \mathrm{~W}_{\mathrm{EC}}+150 \mathrm{~W}_{\mathrm{C}}
$$

where $\mathrm{TBK}$ is expressed in $\mathrm{mEq}$ and $\mathrm{W}_{\mathrm{EC}}$ and $\mathrm{W}_{\mathrm{C}}$ are expressed in $\mathrm{kg}$. It is evident that $\mathrm{W}_{\mathrm{C}}=\mathrm{TBW}-\mathrm{W}_{\mathrm{EC}}$. Therefore, if TBK and TBW are known, the equation may be solved for $\mathrm{W}_{\mathrm{EC}}$ by substituting $\left(\mathrm{TBW}-\mathrm{W}_{\mathrm{EC}}\right.$ ) for $\mathrm{W}_{\mathrm{C}}$ :

$$
\mathrm{W}_{\mathrm{EC}}=1.027 \mathrm{TBW}-0.00685 \mathrm{TBK}
$$

Utilizing $1619 \mathrm{mEq}$ for TBK and $18.3 \mathrm{~kg}$ for TBW, it is found that $\mathrm{W}_{\mathrm{EC}}$ of the reference boy is $7.7 \mathrm{~kg}$. Therefore, $\mathrm{W}_{\mathrm{C}}$ is $10.6 \mathrm{~kg}$.

\section{MINERALS}

Minerals in the body may be partitioned into those in hard tissues (bones and teeth), subsequently referred to as osseous minerals, and those in extracellular and celluiar water, subsequently referred to as nonosseous minerals. The term "minerals" in this context is used to refer to minerals and mineral salts.

${ }^{2}$ The correction was based on the water, protein, and carbohydrate content of the reference boy and on data summarized by Pinson (19) concerning the quantity of rapidly exchangeable hydrogen in protein and carbohydrate. 
Table 1. Height, weight, TBW, and TBK of 9-year-old reference boy

\begin{tabular}{lcccc}
\hline & $\begin{array}{c}\text { Height } \\
(\mathrm{cm})\end{array}$ & $\begin{array}{c}\text { Wt } \\
(\mathrm{kg})\end{array}$ & $\begin{array}{c}\text { Water } \\
(\mathrm{kg})\end{array}$ & $\begin{array}{c}\text { Potassium } \\
(\mathrm{mEq})\end{array}$ \\
\hline Studies of TBW $^{1}$ & 131.6 & 27.7 & 18.4 & \\
Studies of TBK $^{2}$ & 134.9 & 30.1 & & 1740 \\
Reference boy & 132.0 & 28.0 & 18.3 & 1619 \\
\hline
\end{tabular}

'Based on 11 males 7 to 11 years of age (see text) uncorrected for exchange of deuterium with $\mathrm{H}$ atoms in organic molecules.

Based on 64 males 8 to 10 years of age $(11,13)$.

\section{OSSEOUS MINERALS}

Christiansen and Rödbro (5) have demonstrated that the bone mineral content of the distal portion of the forearm measured in vivo by the two-dimensional photon absorptiometric method correlates reasonably well with total body content of calcium. Examination of the data of Christiansen et al. (6) from study of boys from 7 to 19 years of age indicates that the ratio of body calcium to height is relatively constant from 7 to 14 years of age (but increases rapidly thereafter). The mean calcium-to-height ratio of 79 boys from 7 to 14 years of age was $2.52 \mathrm{~g} / \mathrm{cm}$. Thus, for the $9-$ year-old reference boy with height of $132.0 \mathrm{~cm}$, we calculated the total body calcium to be $0.333 \mathrm{~kg}$. Nearly all body calcium is present in osseous minerals, and in the adult, calcium accounts for $34 \%$ of osseous minerals (1). We have assumed that a similar relationship applies at age 9 years. The content of osseous minerals in the 9 -year-old reference boy is therefore $0.979 \mathrm{~kg}(0.333 \mathrm{~kg} \div$ $0.34)$.

\section{EXTRACELLULAR AND CELLULAR NONOSSEOUS MINERALS}

In extracellular fluid six components account for well over $99 \%$ of mineral weight. ${ }^{3}$ The combined weight of these six components is $9.4 \mathrm{~g} / \mathrm{kg}$ of water. Similarly, in cellular fluid six components account for more than $99 \%$ of the total. ${ }^{4}$ The combined weight of these components is $9.0 \mathrm{~g} / \mathrm{kg}$ of water. The quantity of nonosseous minerals and mineral salts in the 9-year-old reference boy is therefore $167.8 \mathrm{~g}$ (extracellular, $72.4 \mathrm{~g}$; cellular, $95.4 \mathrm{~g}$ ).

\section{PROTEIN AND CARBOHYDRATE}

Whole-body chemical analyses indicate that in the newborn infant the ratio of nitrogen to potassium is $469 \mathrm{mg} / \mathrm{mEq}(21)$, and in the adult, the ratio is $461 \mathrm{mg} / \mathrm{mEq}(10)$. Utilizing the ratio of $461 \mathrm{mg} / \mathrm{mEq}$, the body content of nitrogen of the 9-year-old reference boy is $746 \mathrm{~g}\left(1619 \mathrm{mEq} \mathrm{K} \times \frac{0.461 \mathrm{~g} \mathrm{~N}}{\mathrm{mEq} \mathrm{K}}\right)$ and the body content of protein (nitrogen $\times 6.25$ ) is $4665 \mathrm{~g}$. The nonprotein nitrogen of the body is included in this calculation and is thus represented as protein equivalents.

We have assumed that in the 9-year-old, as in the adult (17), glycogen accounts for approximately $0.5 \%$ of body weight or 140 $\mathrm{g}$ in the $28 \mathrm{~kg}$ reference boy.

\section{COMPOSITION OF 9-YEAR-OLD REFERENCE BOY}

The composition of the 9-year-old reference boy is summarized in Table 2. Compared with the reference male adult (1), the 9year-old boy is relatively lean ( $13.4 \%$ versus $15.3 \%$ of body weight accounted for by fat) and differs to some extent in composition of fat-free body weight. In the reference male adult water, protein and minerals account for $73.7,19.4$, and $6.9 \%$, respectively, of FFBM.

Utilizing densities for body components as summarized by

The concentrations of six components $(\mathrm{mg} / \mathrm{kg}$ of extracellular water) are as follows: chloride, 4,047; sodium, 3,312; bicarbonate, 1,830; potassium, 156; calcium, 50; magnesium, $18(20)$.

The concentrations of six components $(\mathrm{mg} / \mathrm{kg}$ of cellular water) are as follows potassium, 5,865; phosphate, 1.720; bicarbonate, 610; sulfate, 320; magnesium, 305; sodium, $230(12)$
Table 2. Composition of 9-year-old reference boy (height, $132 \mathrm{~cm}$; weight, $28 \mathrm{~kg}$ )

\begin{tabular}{|c|c|c|c|}
\hline \multirow[b]{2}{*}{ Component } & \multicolumn{3}{|c|}{ Composition } \\
\hline & $\mathrm{kg}$ & $\begin{array}{c}\% \text { whole } \\
\text { body }\end{array}$ & $\begin{array}{c}\% \text { fat- } \\
\text { free }\end{array}$ \\
\hline \multicolumn{4}{|l|}{ Fat-free } \\
\hline Water & 18.30 & 65.4 & 75.5 \\
\hline Protein & 4.66 & 16.6 & 19.2 \\
\hline Carbohydrate & 0.14 & 0.5 & 0.6 \\
\hline Minerals & 1.15 & 4.1 & 4.7 \\
\hline Total & 24.25 & $86.6 \%$ & \\
\hline Fat & 3.75 & $13.4 \%$ & \\
\hline
\end{tabular}

Brožek et al. $(1)^{5}$ and, for convenience, including the small amount of glycogen with the water compartment, calculated whole-body density is 1.064 for the reference male adult and 1.054 for the 9year-old reference boy. Calculated density of FFBM is 1.100 for the reference male adult and 1.082 for the 9 -year-old reference boy. The formula for calculating the fractions of the body comprised of fat $(f)$ and fat-free tissue ( $f f)$ from body density $\left(D_{B}\right)$ may be derived as follows:

$$
D_{B}=\frac{f+f f}{V_{f}+V_{f f}}=\frac{1}{\frac{f}{D_{f}}+\frac{1-f}{D_{f f}}}
$$

where $V_{f}$ and $V_{f f}$ are the respective volumes of fat and fat-free tissue, and $D_{f}$ and $D_{f f}$ are the respective densities. If 0.9007 is substituted for $\mathrm{D}_{\mathrm{f}}$ and 1.082 for $\mathrm{D}_{\mathrm{ff}}$, the following equation is obtained for the 9-year-old reference boy:

$$
f=\frac{5.376}{D_{B}}-4.968
$$

\section{COMMENT}

For estimating the body composition of a 9-year-old reference boy, it would be desirable to have TBW and TBK determined in the same group of representative 9-year-old boys. However, we consider the data available to be reasonably satisfactory for all parameters except TBW. It was, unfortunately, necessary to base the estimate of TBW on only 11 determinations. These were made by four groups of investigators and concerned boys from 7 to 11 years of age.

Because the data on TBW appeared to be the weakest link in our derivation of the body composition of the reference boy, we have utilized an alternate approach as a check on the values used. Equation (1) can also be solved if a value is available for $\mathrm{W}_{\mathrm{EC}}$ or $\mathrm{W}_{\mathrm{C}}$. We have estimated $\mathrm{W}_{\mathrm{EC}}$ from data on thiosulfate space of 9year-old boys $(20.6 \%$ of body weight) $(2,3)$, using a factor of 1.4 to convert thiosulfate space to extracellular water $\left(\mathrm{W}_{\mathrm{EC}}=20.6 \%\right.$ $\times 1.4=28.84 \%$ of body weight). ${ }^{6}$ Equation (1) may then be written as follows:

$$
\mathrm{TBK}=4 \mathrm{~W}_{\mathrm{EC}}+150\left(\mathrm{TBW}-\mathrm{W}_{\mathrm{EC}}\right)
$$

Substituting $1619 \mathrm{mEq}$ for TBK and $8.075 \mathrm{~kg}$ (i.e., $28.84 \% \times 28$ $\mathrm{kg}$ ) for $\mathrm{W}_{\mathrm{EC}}$, TBW is found to be $18.65 \mathrm{~kg}$ and fat-free body mass is $24.6 \mathrm{~kg}$. Thus, an independent method of calculating TBW yields a result in rather good agreement with the 11 measurements of 7- to 11-year-old boys.

Fat, 0.9007; water, 0.9937; protein, 1.340; osseous minerals, 2.982; nonosseous minerals, 3.317 .

${ }^{6}$ The factor 1.4 was calculated from data concerning TBW and TBK of normal. young adult males studied by Forbes et al. (14) (from equation 2, W $\mathrm{FC}_{\mathrm{EC}}$ was calculated to be $38.5 \%$ of TBW) and data concerning TBW and thiosulfate space of adult males studied by Edelman et al. (8) (thiosulfate space was $27.2 \%$ of TBW). In each case, we have corrected the TBW values reported by the investigators to adjust for exchange of deuterium with hydrogen of organic molecules. 
Fortunately, the constancy of total body calcium per unit of height from 7 to 14 years of age permits use of the large number of measurements made by Christiansen et al. (6), and there is little difficulty in arriving at an estimate of osseous mineral for the reference boy. Although the extent of mineralization of the skeleton is likely to be proportional to density of the bones of the distal forearm as indicated by photon absorptiometry, there is no assurance that the same quantitative relationship obtains in the child as in the adult. Neither is it certain that the ratio of nitrogen to potassium in FFBM is the same in the 9-year-old as in the newborn and the adult. However, it seems to us most unlikely that our assumptions regarding bone mineral content or nitrogen to potassium ratio will introduce important errors.

As an independent test of the validity of the calculated composition of the 9-year-old reference boy, we have compared body density of this reference by (1.054) with that of the 40 boys studied sequentially by Pařiźková (18). Mean body density determined by hydrostatic weighing of these 40 boys was 1.057 at a mean age of 10.7 years and 1.059 at a mean age of 11.7 years. Thus, the body density calculated from the components of the 9-year-old reference boy seems reasonable.

If the composition of fat-free body mass of the 9-year-old boy is similar to that presented in Table 2, it is clear that data from indirect measurements of body composition (TBW, ${ }^{40} \mathrm{~K}$ counting, and body density) must be interpreted on an age-specific basis. If constants appropriate for the reference adult male were utilized, fat content of the body of the 9-year-old reference boy would be calculated to be $11.3,15.1$, and $19.7 \%$ of body weight, respectively, from determinations of TBW, TBK, or body density rather than the $13.4 \%$ of body weight that results from utilization of agespecific constants.

It is evident that body composition of other boys of different ages and of girls can be calculated in a similar manner. Use of age-and sex-specific constants will aid greatly in interpretation of data from indirect measurements of body composition.

\section{REFERENCES AND NOTES}

1. Brožek, J., Grande, F., Anderson, J. T., and Keys, A.: Densitometric analysis of body composition: revision of some quantitative assumptions. Ann. N. Y. Acad. Sci., 110: 113 (1963).
2. Burmeister, W.: Die Beziehung zwischen Extrazellular - (Thiosulfat)-Raum und Zellmasse während des Wachstums. Ann. Paediatr., 198: 185 (1962).

3. Burmeister, W.: Der Extrazellular-(Thiosulfat)Raum im menschlichen Organismus während des Wachstums. Ann. Univ. Sarav. Med., 9: 167 (1961/62).

4. Cheek, D. B., Mellits, D., and Elliott, D.: Body water, height, and weight during growth in normal children. Am. J. Dis. Child., 112: 312 (1966).

5. Christiansen, C.. and Rödbro, P.: Estimation of total body calcium from the bone mineral content of the forearm. Scand. J. Clin. Lab. Invest., 35: 425 (1975).

6. Christiansen, C., Rödbro, P., and Thöger Nielsen, C.: Bone mineral content and estimated total body calcium in normal children and adolescents. Scand. J. Clin. Lab. Invest., 35: 507 (1975).

7. Dickerson, J. W. T.: Changes in the composition of the human femur during growth. Biochem. J., 82: 56 (1962).

8. Edelman, I. S., Haley, H. B., Schloerb, P. R., Sheldon, D. B., Friis-Hansen, B. J. Stoll, G., and Moore, F. D.: Further observations on total body water. I. Normal values throughout the life span. Surg. Gynecol. Obstet., 95: I (1952).

9. Fomon, S. J.: Infant Nutrition. Ed. 2, pp. $34-94$ (W. B. Saunders, Philadelphia, 1974).

10. Forbes, G. B.: Methods for determining composition of the human body. Pediatrics, 29: 477 (1962).

11. Forbes, G. B.: Growth of the lean body mass in man. Growth, 36: 325 (1972).

12. Forbes, G. B.: Disturbances of water and electrolytes. In: Pediatric Neurology. Ed. 2 Chap. 3 (Harper and Row, Hagerstown, MD, 1975).

13. Forbes, G. B.: Unpublished data.

14. Forbes, G. B., Schultz, F., Cafarelli, C., and Amirhakimi, G. H.: Effects of body size on potassium-40 measurement in the whole body counter (tilt-chair technique). Health Phys., 15: 435 (1968).

15. Friis-Hansen, B.: Changes in body water compartments during growth. Acta Paediatr. Suppl., 110 (1957).

16. Hamill, P. V. V., Drizd, T. A., Johnson, C. L., Reed, R. B., Roche, A. F., and Moore, W. M.: Physical growth: National Center for Health Statistics percentiles. Am. J. Clin. Nutr., 32: 607 (1979).

17. Levine, R.: Carbohydrate metabolism. In: G. G. Duncan: Diseases of Metabolism. Ed. 5. p. 105 (W. B. Saunders, Philadelphia, 1964).

18. Pařiźková, J.: Growth and growth velocity of lean body mass and fat in adolescent boys. Pediatr. Res., 10: 647 (1976).

19. Pinson, E. A.: Water exchanges and barriers as studied by the use of hydrogen isotopes. Physiol. Rev., 32: 123 (1952).

20. Pitts, R. F.: Physiology of the Kidney and Body Fluids, Ed. 3, Chap. 2 (Year Book Medical Publishers, Chicago, 1974).

21. Ziegler, E. E., O’Donnell, A. M., Nelson, S. E., and Fomon, S. J.: Body composition of the reference fetus. Growth, 40:329 (1976).

22. The authors are grateful to G. B. Forbes for criticisms of the manuscript and for unpublished data on total body potassium.

23. Requests for reprints should be addressed to: Samuel J. Fomon, M.D., Department of Pediatrics, College of Medicine, University of Iowa, Iowa City, IA 52242 (USA).

24. This research was supported in part by U.S.P.H.S. grant HD 07578.

25. Received for publication August 13, 1980

26. Accepted for publication October 2, 1980 